\title{
Problem Solving Ability of Junior High School Students Viewed by Mathematical Resilience
}

\author{
Syahrur Rohmah*, Tri Atmojo Kusmayadi, Laila Fitriana \\ Postgraduate School of Mathematics Education, Sebelas Maret University, Indonesia
}

Received April 5, 2020; Revised May 19, 2020; Accepted June 4, 2020

Copyright (C2020 by authors, all rights reserved. Authors agree that this article remains permanently open access under the terms of the Creative Commons Attribution License 4.0 International License

\begin{abstract}
Mathematical resilience is one of the non-intellectual aspects that students must have to overcome anxiety, so students will have a diligent, persistent and confident attitude to be able to solve problems in mathematics. Problem solving skills are high-level thinking skills that must be possessed by students. This research is a quantitative descriptive study with 274 students from three junior high schools in Karanganyar Regency, Indonesia, respectively with high, moderate, and low school categories. The purpose of this study is to find out which kind of students have better mathematical problem solving abilities among students with high, medium and low mathematical resilience categories. The data analysis technique used is the one-way ANOVA with unbalanced cells and post hoc test using the Scheffe method. Based on the statistical analysis, the problem solving skills of students who have high resilience are as effective as those of students who have moderate resilience. Students with moderate resilience have the same effective problem solving skills as those who have low resilience, and students with high resilience have better problem solving skills than those who have low resilience.
\end{abstract}

Keywords Problem Solving Ability, Resilience, Mathematics

\section{Introduction}

The rapid development of globalization occurring in the $21^{\text {st }}$ century has now brought changes in the field of education, especially in understanding teaching and learning. With the changes occurring in the educational process, it is expected that individuals have effective qualifications, such as those in asking questions, solving problems, researching, critical thinking, utilizing technology, expressing thoughts and producing information [1]. Individuals must think mathematically in mastering various important skills in the $21^{\text {st }}$ century in facing incidents and phenomena they encounter at every stage of their lives [2]. The skills possessed by these students can be obtained through the process of learning mathematics, so that the skills possessed can be used to create new and useful ideas, detailing, refining, analyzing, and evaluating their ideas to develop and maximize students' thinking processes in solving events that he met, so students can be successful in their lives and work.

Mathematics has a very important role in developing students' ability to think logically [3]. It means that Mathematics is not a lesson of counting, but a process of reasoning that requires logic. Mathematics is also not a lesson of memorizing formulas, but understanding procedures and communicating procedures in solving problems. The Mathematics subject needs to be provided to all students from elementary school to equip them with the ability to think logically, analytically, systematically, critically, and creatively, as well as the ability to work together. The purpose of students' learning Mathematics, especially problem solving, is to construct new mathematical knowledge through problem solving, get the ability to apply and adapt various correct strategies to solve problems and reflect the process of solving mathematical problems [4].

Mathematics is also one of the most important subjects in formal education that is closely related to daily life, but Mathematics is not an interesting subject for students to learn and the ability to solve mathematical problems among Indonesian students is still low [5,6], because students feel afraid of facing difficulties in learning Mathematics [7]. The ability to solve problems is one of the aspects of the ability of a high level of thinking in solving problems when students have difficulty in Mathematics. If students' high level of thinking ability is developed, they will be able to solve problems indirectly [8-10]. Individuals can find the right solution for a problem through the problem solving process.

In solving a problem, individuals use mental activity in 
managing their thoughts well, taking advantage of their prior knowledge, controlling and reflecting on the processes and outcomes of their thinking to help solve problems [11]. One focus of the Mathematics curriculum at schools is the problem solving process, in which it is expected that in learning, the students can gain experience to transfer and apply the skills and knowledge learned to solve problems [12-14]. Through problem solving activities, aspects of mathematical ability such as applying rules to non-routine problems, pattern discovery, generalization, mathematical communication and others can be better developed. Problem solving skills involve all aspects of knowledge (memory, understanding, application, analysis, synthesis, and evaluation) that can be seen as the process of students' discovering a combination of rules that have been studied beforehand and that are used to solve problems, not just the process of applying rules that are known, but producing new lessons. Effective problem solving requires students to identify, determine and solve problems using logic, literary thinking and creativity [15].

Students will carry out problem solving procedures if they are given some types of a mathematical problem. In the process of problem solving, there are usually routine and non-routine procedures to solve the problem, in which there are differences in the practice of calculation. The non-routine problems require planning that are not only applications of formulas, theorems, propositions. The purpose of non-routine problems is to place students in situations in which they need to think mathematically and then be proficient in mathematical thinking through repetitive situations, while routine problems require more algorithmic calculations [16]. Non routine problems require a different reasoning and the application of certain heuristic strategies such as organizing or classifying data in different ways [17]. Non-routine problems in learning mathematics can practice the reasoning power and critical thinking of students in solving problems, the reasoning power of students will increase because they often face non-routine problems, and students will be trained in solving problems.

Activities in solving these problems are in line with Polya's strategy to solve the problem. There are four steps of the problem solving process that can be used as a measurement aspect of problem solving according to Polya, consisting of: understanding the problem, preparing the plan, implementing the plan, and reviewing the results [18]. Understanding the problem can be in the form of reading the problem, determining the keywords of the problem element. Preparing the plan can be in the form of mathematical pictures based on problems, determining questions, determining mathematical concepts that will be used in problem solving. Implementing the plan can be in the form of a mathematical operation to get the results of problem solving. The students should correct the results, confirm the answers to the problem, check the problem with the solution obtained, check the mathematical keywords in the problem with the solution, and make sure about the answer given.

Problem solving skills are considered as an important aspect in Mathematics and even as competencies needed in $21^{\text {st }}$ century skills $[14,19]$. However, based on facts in the field, students' problem solving skills are still low. The results of interviews conducted by the researcher with Mathematics teachers in a State Junior High School in Karanganyar District show that the students' problem solving skills are still lacking because they do not understand the purpose asked for the problem and do not understand the procedures to be used in solving the problem.

According to the teacher's view, the difficulty encountered by the students, especially in solving problems, is due to the difficulty of students in understanding the problem, making plans in solving the problem, describing and linking (object) with the knowledge and skills possessed by the students. In addition to conducting interviews with teachers, the researcher also provided preliminary tests to students to determine students' problem solving skills. Some of the problems found so far are that students do not have good problem solving skills and that students have limited learning resources that can guide their independent learning.

The preliminary test results of the problem solving skills of $8^{\text {th }}$ grade students of SMP Negeri 2 Kebakkramat show that the success of students in understanding the problem (51.51\%) is considered as moderate, the success of students in planning the solution (35.60\%) is categorized as low, the success of students in implementing the plan (40.15\%) is categorized as moderate, and the success of students in reviewing the results $(23.48 \%)$ is categorized as low.

The students find it difficult in the process of solving the problem. These difficulties make the students feel afraid and avoid challenging problem solving activities. Low mathematical problem solving skills are an important issue that must be solved. The problem solving process requires a very high concentration along with patience, perseverance and an optimistic attitude in order to create students' enthusiasm in learning Mathematics. The students still consider Mathematics as a difficult subject and think that counting is not fun so that it makes them feel insecure and give up easily [20]. Therefore, one aspect of learning that needs attention is the non-intellectual aspect [21], which is affective skills, such as perseverance, not giving up easily, curiosity and self-confidence, and understanding the role of mathematics in real life. The students need to develop positive and adaptive attitudes towards mathematics that will enable them to continue learning to reduce [22] and even eliminate negative influences, so that students' resilience can be developed [23]. Mathematical resilience is one of the students with positive attitudes must have to overcome anxiety, so that they will have a determined, persistent and confident attitude. Resilience is the ability of individuals to encounter 
and respond positively to the challenges they must face and they can develop their abilities in facing those challenges $[24,25]$. Mathematical resilience is defined as the ability to endure (object) when faced with difficulties, work collaboratively with peers, have the language proficiency needed to express an individual's understanding or lack of understanding, and withstand difficulties related to learning [26], and the ability to have a positive outlook despite having difficulties [27]. Students who have good mathematical resilience always show an attitude of perseverance when facing a challenge and problem [28]. Mathematical resilience measures students' attitudes in learning Mathematics by using three correlated factors: Value, Struggle, and Growth [29]. A student is categorized to have mathematical resilience if they have the following indicators of mathematical resilience as follow [30]:

1. Has the confidence that Mathematics is something valuable and deserves to be learned and studied.

2. Has the will and persistence in learning Mathematics, despite experiencing difficulties, obstacles and challenges.

3. Has confidence in themselves that they are able to learn and master Mathematics, both based on an understanding of Mathematics, the ability to create strategies, the help of devices and others, and also the experience they possessed.

4. Has characteristics of defensive, never give up, and always gives a positive response in learning Mathematics.

The success of resilience in education is also not only influenced by the students themselves, but also by the surrounding environment that can make them successful and resilient in every challenge [31]. Several studies have identified mathematical resilience among students [32], stating that students with good mathematical endurance have the will to develop mathematical skills, are reflective and always think hard, make efforts when learning Mathematics. The students with good mathematical endurance have growth confidence related to their abilities; when they are in trouble, they remain confident that they will be able to solve the problem [33]. One of the factors that might influence students' problem solving skills is the students' mathematical resilience. The students who have different categories of resilience will also have many and varied problem solving skills. Thus, the objective of this study is to determine who will provide better problem solving skills among students with high, moderate and low resilience.

\section{Methodology}

This type of research is quantitative descriptive. The population of this study was all students of Junior High Schools in Karanganyar District and the subject of the study was $8^{\text {th }}$ grade students in Karanganyar District. The sample in this study was obtained by taking 3 classes from 3 State Junior High Schools in Karanganyar District. The sampling was done by stratified cluster random sampling. The population of Junior High Schools in Karanganyar District will be divided into three categories, consisting of high, moderate and low school categories. Based on the categorization of the average national examination scores in Mathematics of students in the academic year of 2017/2018, out of 51 schools, there are 7 schools in the high category, 26 schools in the moderate category, and 18 schools in the low category. The subjects of this study were 274 students who were divided into high, moderate and low resilience categories.

The instrument used in this study was an essay test to measure students' problem solving skills and a mathematical resilience questionnaire. The mathematical resilience questionnaire consisted of 40 statement items. In this study, the validity test used was the content validity test by the validator. The problem solving skill test in this study was validated by 4 experts, consisting of 3 Mathematics Education lecturers and 1 Mathematics teacher, while the mathematical resilience questionnaire was validated by 3 experts of Psychology lecturers. After obtaining the results of the validation of the test of problem solving skills and mathematical resilience questionnaire, it will be tested on 64 students outside the study sample.

Based on the data that has been collected, for the test of problem solving skills, the analysis will cover the reliability test, the level of difficulty, and distinguishing power for each item. Based on the calculation of the level of difficulty and different power, the item to be disposed of is item number 3 because the criteria for the difference in power are not good, namely $r_{p b i s}<0,3$. Removing the item does not affect the indicators in the grid used, because it has been represented by another item. Reliability test conducted in research using the Crobanch Alpha formula. Based on the results of the reliability calculation, the reliability coefficient is more than 0.6 , it can be concluded that the problem solving ability test is reliable. In the mathematical resilience questionnaire, the analysis will cover the internal consistency test and reliability test using the Cronbach Alpha technique. This study, in order to calculate the internal consistency of the $i$-point, uses the formula of Karl Pearson product moment correlation. After that, a test of problem solving ability and a mathematical resilience questionnaire are then given to the research sample.

The data collection techniques in this study were an essay test of problem solving skills and a mathematical resilience questionnaire. The data analysis technique of this study were a one-way ANOVA statistical test with unbalanced cells and based on test scores of problem solving skills and mathematical resilience questionnaires which were then categorized based on the mathematical resilience categories of student scores. In this study, students' mathematical resilience was grouped into three 
categories, consisting of the high, moderate and low.

\section{Results and Discussion}

In this study, the mathematical resilience questionnaire has been validated by experts and 40 statement items have been tested and they will be given to students in three school categories, in order to obtain data on the numbers of students who have a high, moderate and low category of resilience in each school. The following are the results of the mathematical resilience questionnaire analysis listed in Table 1.

Table 1. Students Mathematical Resilience Distribution

\begin{tabular}{|c|c|c|c|c|}
\hline \multirow{2}{*}{$\begin{array}{l}\text { Mathematical } \\
\text { Resilience } \\
\text { Category }\end{array}$} & \multicolumn{3}{|c|}{ School Category } & \multirow{2}{*}{$\begin{array}{l}\text { Number of } \\
\text { Students }\end{array}$} \\
\hline & High & Medium & Low & \\
\hline High & 9 & 55 & 9 & 73 \\
\hline Medium & 42 & 28 & 40 & 110 \\
\hline Low & 38 & 13 & 40 & 91 \\
\hline $\begin{array}{l}\text { Number of } \\
\text { Students }\end{array}$ & 87 & 96 & 85 & 274 \\
\hline
\end{tabular}

In Table 1, the number of students categorized to have high resilience category is 73 , the number of students categorized to have moderate resilience category is 110 , and the number of students categorized to have low resilience category is 91 . Based on data analysis, students with moderate resilience category are more than those with high and low resilience category. Students with moderate mathematical resilience will regard the problem as a burden but will not give up and try to solve the mathematical problem as much as they can. Students with low category are more than those with high resilience. Students with low mathematical resilience will experience anxiety and experience disappointment when dealing with mathematical problems and cannot solve the given problem. Students with high mathematical resilience have a positive and optimistic attitude in carrying out Mathematics learning so that they will be confident of their ability to solve a problem if they find a difficult problem. Furthermore, the following are the results of test analysis of problem solving ability in Table 2.

Table 2. Students Problem Solving Ability Distribution

\begin{tabular}{ccccc}
\hline Problem & \multicolumn{3}{c}{ School Category } & Number of \\
\cline { 2 - 5 } $\begin{array}{c}\text { Solving } \\
\text { Ability } \\
\text { Category }\end{array}$ & High & Medium & Low & Students \\
\hline High & 37 & 22 & 17 & 76 \\
\hline Medium & 32 & 52 & 34 & 118 \\
\hline Low & 20 & 22 & 38 & 80 \\
\hline $\begin{array}{c}\text { Number of } \\
\text { Students }\end{array}$ & 89 & 96 & 89 & 274 \\
\hline
\end{tabular}

In Table 2, the number of students who have high problem solving skills is 76 , the number of students who have moderate problem solving skills is 118 , and the number of students who have low problem solving skills is 80. The number of students who have high problem solving skills is the least compared to that of students who have moderate or low problem solving skills. This means that students are still lacking in problem solving skills. Students who have the ability to solve problems means that they are able to understand the problem by elaborating on what is known and asked about the problem. Students are still confused when asked to reconstruct questions into mathematical sentences so that they cannot solve these problems.

Students having low problem solving skills means that they still do not understand the problem, they still do not understand the plan to solve, cannot solve the problem according to plan, and they do not re-check all the steps that have been done. Students having high problem solving skills means that they can write down what is known and asked on the problems, they are good in choosing strategies to solve problems, they can reconstruct questions into mathematical sentences, they do not experience obstacles in carrying out arithmetic operations that will be used and they have been able to implement strategies to solve mathematical models or problems and or outside Mathematics. The last stage is to re-check the answers. Students are quite capable of explaining or interpreting the results according to the primary problem, but they do not carry out the stages of re-checking. Next, the following are the results of students' mathematical resilience questionnaire and analysis of students' problem solving skills. In Table 3.

Table 3. Grouping between Problem Solving Ability and Students Mathematical Resilience

\begin{tabular}{ccccc}
\hline Problem & \multicolumn{3}{c}{ Mathematical Resilience Category } & Number of \\
\cline { 2 - 4 } $\begin{array}{c}\text { Solving } \\
\text { Ability } \\
\text { Category }\end{array}$ & High & Medium & Low & Students \\
\hline High & 20 & 37 & 19 & 76 \\
\hline Medium & 44 & 38 & 36 & 118 \\
\hline Low & 9 & 35 & 36 & 80 \\
\hline $\begin{array}{c}\text { Number of } \\
\text { Students }\end{array}$ & 73 & 110 & 91 & 274 \\
\hline
\end{tabular}

In Table 3, students who have high problem solving skills are dominantly categorized as those who have moderate mathematical resilience. Students who have high resilience and have high problem solving skills have been able to answer the problem solving skill test well. Students are able to write down what is known and asked of the questions, students are procedurally able to work on the questions given because they do not easily give up and can confidently complete the problem solving skill test.

Students who have high resilience and have the problem solving skills are able to work on the given problems procedurally, but they are not careful in the calculation process, so the final answer is wrong. Students who have high resilience and low problem solving skills can identify 
the elements that exist in the problem, but they cannot determine the right strategy to solve the given problem.

Students who have moderate and low resilience and students who have high problem solving skills have mastered the concepts in the material in the test so that it makes them easy to solve problems. Students who have moderate and low resilience and students who have moderate problem solving skills can solve problems by using correct but incomplete strategies and procedures because they are not thorough in answering questions.

Students who have moderate resilience and low problem solving skills still do not understand the mastery of the material being tested so that they experience difficulties in working on the test. Students who have low resilience and low problem solving skills solve word problems in an unstructured way, which is caused by the lack of students' understanding of how to write down the explanation in the problem into a problem solving model to be used. At the stage of planning to solve problems, students cannot predict problem solving strategies correctly, so that they experience obstacles in converting information that is known from the problem into mathematical modeling.

In this study, because the number of each sample in each school is not the same, (subject) tries to find out which sample gives better problem solving skills among students with high, moderate, and low resilience, then it uses a one-way analysis of variance statistical test with unbalanced cell. The results of data analysis will be used in the one-way ANOVA statistical test with unbalanced cells in Table 4.
Based on Table 4, the average score of students' mathematical problem solving skill who have a high resilience is 62.75 , the average score of students' problem solving skills has a moderate resilience of 59.04, and the average score of students who have low resilience is 54.71 . After the score data of students' problem solving score of students' are grouped according to each categorization of mathematical resilience, the hypotheses of the data will be tested using one-way ANOVA with unbalanced cells to see the effect of independent variables of students' mathematical resilience and for the dependent variable, it uses students' mathematical problem solving skills by comparing the averages of several populations. It will be determined whether or not the three categories of mathematical resilience have the same effect on students problem solving abilities (such as $\mathrm{H}_{0}$ ), or at least two categories do not have the same effect on students' problem solving skills (such as $\mathrm{H}_{1}$ ). The statistical test results can be seen in the following Table 5 .

Based on Table 5, it is obtained if the critical area $=\{\mathrm{F} \mid$ $\left.\mathrm{F}>\mathrm{F}_{\alpha ; \mathrm{k}-1 ; \mathrm{N}-\mathrm{k}}\right\}$ with $\mathrm{F}_{0,05 ; 2 ; 270}=3.029$, and $\mathrm{F}_{\text {obs }}=4.710$ is a critical area, then $\mathrm{H}_{0}$ is rejected. In conclusion, it is not true that all three categories of mathematical resilience have the same effect on students' problem solving skills. Moreover, further tests will be carried out in this study using the post hoc test with the Scheffe method to find out which kind of students have better problem solving skills among students who have high, moderate or low mathematical resilience skills. The results of the post hoc test analysis with the Scheffe method are presented in Table 6.

Table 4. Data of Students' Mathematical Resilience

\begin{tabular}{|c|c|c|c|c|c|c|}
\hline \multicolumn{2}{|c|}{$\begin{array}{l}\text { Mathematical Resilience } \\
\text { Category }\end{array}$} & $\mathrm{N}$ & Mean & Standar Deviasi & Minimum Score & Maximum Score \\
\hline & & 73 & 62.75 & 11.65 & 38 & 91 \\
\hline & & 110 & 59.04 & 16.69 & 16 & 94 \\
\hline & & 91 & 54.71 & 17.19 & 13 & 97 \\
\hline \multicolumn{2}{|c|}{ Number of Students } & 274 & & & & \\
\hline & Sum of Squares & Df & Mean Square & $F_{\text {obs }}$ & $\mathrm{F}_{\alpha}$ & $\mathrm{P}$ \\
\hline $\begin{array}{l}\text { Between } \\
\text { Groups }\end{array}$ & 2376.275 & 2 & 1188.137 & 4.710 & 3.029 & $<0.05$ \\
\hline $\begin{array}{l}\text { Within } \\
\text { Groups }\end{array}$ & 68113.922 & 270 & 252.274 & - & & \\
\hline Total & 70490.197 & 272 & - & - & & \\
\hline
\end{tabular}

Table 6. Post-ANOVA Multiple Comparisons with Scheffe Method

\begin{tabular}{cccccc}
\hline \multirow{4}{*}{$\begin{array}{c}(\mathrm{I}) \\
\text { Mathematical Resilience }\end{array}$} & $\begin{array}{c}(\mathrm{J}) \\
\text { Mathematical Resilience }\end{array}$ & $\begin{array}{c}\text { Mean Difference } \\
(\mathrm{I}-\mathrm{J})\end{array}$ & Sig. & $\mathrm{P}$ \\
\hline \multirow{3}{*}{ Scheffe } & \multirow{2}{*}{ High } & Moderate & 3.644 & 0.317 & $>0.05$ \\
\cline { 2 - 6 } & \multirow{2}{*}{ Moderate } & Low & $7.643^{*}$ & 0.010 & $<0.05$ \\
\cline { 2 - 6 } & \multirow{2}{*}{ Low } & High & -3.644 & 0.317 & $>0.05$ \\
\cline { 2 - 6 } & & Low & 3.999 & 0.210 & $>0.05$ \\
\cline { 2 - 6 } & & Low & $-7.643^{*}$ & 0.010 & $<0.05$ \\
\cline { 2 - 6 } & & Moderate & -3.999 & 0.210 & $>0.05$ \\
\hline
\end{tabular}


Based on the results of the post hoc test analysis with the Scheffe method on Table 6, among students in the category of high and moderate resilience, it obtained a significant value of $0.317>0.05$, so that $\mathrm{H}_{0}$ is accepted. It means that the problem solving skills of students in the high mathematical resilience category is as effective as those in the moderate mathematical resilience category. The problem solving skills among students who are categorized as students of high and low resilience obtained a significance value of $0.010<0.05$, so $\mathrm{H}_{0}$ is rejected. This means that students who are categorized as students with high mathematical resilience have different effects than students who have the low mathematical resilience category. This is because the average score of students in the high mathematical resilience category (62.75) is better than students in the low mathematical resilience category (54.71) in problem solving skills. It can be concluded that the problem solving skills of students in the high mathematical resilience category is better than students who are in the low mathematical resilience category.

Among the students in the moderate mathematical resilience category and students in the low resilience category, a significance value of $0.210>0.05$ is obtained, meaning that $\mathrm{H}_{0}$ is accepted. Hence, students' problem solving skills with moderate mathematical resilience are as effective as students who are categorized in low mathematical resilience. Students who have high mathematical resilience do not give up easily and always try to face the difficulties that exist in Mathematics, always have an open attitude, confidence and always have the spirit to be successful. Students who have moderate resilience usually have an up and down spirit and tend to be unstable in attitude, while students with the low mathematical resilience category have an attitude of easy to give up, avoid problems and do not have the spirit to rise. Students who have high resilience who face difficulties are able to achieve high levels of academic motivation and performance, while students with low resilience tend to regard problems as a burden in their lives.

Resilience in solving problems in studying Mathematics in Japan plays an important role in technology and science advances [34]. Students can be directed to see abilities that can be developed over time with good efforts and strategies, as well as assistance from others and make it more resilient if they find ways to study diligently [35]. An individual who has good mathematical endurance will survive when faced with difficulties in solving mathematical problems because they master the theory of Mathematics learning [36].

Students with strong resilience will do well in Mathematics at school even if the conditions are less favorable. They have the following attitudes: adaptable to the environment; able to face uncertainty, problems and challenges; solve problems logically and flexibly; find creative solutions to challenges; curious and learn from experience; have the ability to control themselves; aware of their feelings.

By understanding students' difficulties in solving the problem of two-variable linear equation system system in terms of mathematical resilience, the teacher can know what needs to be done to prepare students based on mathematical resilience to solve a problem. Developing a meaningful learning process such as choosing the right learning strategy that can facilitate students in the problem solving process. Learning activities with appropriate learning strategies to be able to practice problem solving skills [37]. One of them is by preparing a learning model that is suitable for use by the teacher for the material being taught so that it can improve students' problem solving abilities. Examples of learning models that can be applied by teachers are problem based learning (PBL). PBL is a pedagogical technique that places learning in the context of complex problem solving [38]. PBL offers the potential to help students think rationally and flexibly to take actions based on their knowledge. With the PBL, students can actively solve problems and demand higher thinking skills of students through the learning process because problems that are solved are directly linked to real life, which can increase students' motivation and interest in the material being studied.

In addition to the learning process, students can also improve their problem solving abilities in terms of their mathematical resilience. According to Newman [39], so that someone has high resilience, then the strategy that must be carried out on someone aged 13 to 19 years is a strong social support network, in the form of: (1) The presence of parents who always support what their children do; (2) Having confidence and trying to make a change; (3) Participation in various extracurricular activities; (4) Developing skills to overcome difficulties. It is expected that students must have mathematical resilience with a high category so that students do not easily give up when facing difficulties in the problem solving process. Students who have a strong resilience will understand their students' mathematics. The greater the motivation to learn it is, the more likely they are to persist in solving difficult mathematical problems to be able to improve their problem solving abilities.

\section{Conclusions}

Based on the statistical analysis, the problem solving skills of students who have high resilience is as effective as students who have moderate resilience. Students with moderate resilience have the same effective problem solving skills as those who have low resilience, and students with high resilience have better problem solving skills than those who have low resilience. Students with high mathematical resilience have a positive and optimistic attitude in carrying out Mathematics learning so that they will be confident of their ability to solve problems when 
facing difficulties. Students with high mathematical resilience will show their hard work results better than those who have low mathematical resilience.

Based on the results of the study, students in the problem solving process must first understand the prerequisite material such as operating material in the form of algebra. Students must also master the concepts in the material so that it will be easier for students to understand the material system of two-variable linear equations. Appropriate learning activities such as PBL can train students' problem solving skills. In addition to external aspects, internal aspects of students must be considered as well as mathematical resilience that can improve students' problem solving abilities. Strategies such as a strong social support network to increase mathematical resilience so that someone has a high resilience so that students do not easily give up in solving difficult math problems. In this study, researchers wanted to see how students 'mathematical problem solving abilities when viewed from students' mathematical resilience. The next researcher is expected to be able to examine students' mathematical resilience related to other mathematical abilities.

\section{REFERENCES}

[1] Akbaș, E. E., Cancan, M., \& Kilic, E. Qualification of an Effective Mathematics Teacher from the Perspective of $5^{\text {th }}$ to $8^{\text {th }}$ Grade Secondary School Students, Universal Journal of Education Research, 7(2), 536-549, 2019.

[2] Uyangor, S. M. Investigationof the Mathematical Thinking Processes of Students in Mathematics Education Supported with Graph Theory, Universal Journal of Education Research, 7(1), 1-9, 2019.

[3] Prismana, R. D. E., Kusmayadi, T. A., \& Pramudya, I. Analysis of Difficulties in Mathematics Problem Solving Based on Revised Bloom's Taxonomy Viewed From High Self-Efficacy, Journal of Physics: Conf. Series 1008 012063, 2018.

[4] National Council of Teachers of Mathematics. Principles and Standars For School Mathematics, Reston: (VA: NCTM), 2000.

[5] Nidya, Wulandari, F., \& Jailani. Indonesian Students' Mathematics Problem Solving Skill in PISA and TIMSS, Proceeding of International Conference on Research, Implementation and Education of Mathematics and Science, Yogyakarta State University, 191-198, 2015.

[6] Yerizon, Putra, A. A., \& Subhan, M. Mathematics Learning Instructional Development based on Discovery Learning for Students with Intrapersonal and Interpersonal Inteligence (Preliminary Research Stage), International Electronic Journal of Mathematics Education, 13(3), 97-101, 2018.

[7] Laurens, T., Batlolona, F. A., Batlolona, J. R., \& Leasa, M. How Does Realistic Mathematics Education (RME) Improve Students' Mathematics Cognitive Achievment?, EURASIA Journal of Mathematics, Science and Technology
Education. 14(2), 569-578, 2018.

[8] Kusuma, M. D., Rosidin, U., Abdurrahman, \& Suyatna, A. The Development of Higher Order Thinking Skill (HOTS) Instrument Assessment in Physics Study, IOSR Journal of Reseach \& Method in Education, 7(1), 26-32, 2017.

[9] Abosalem, Y. Assessment Techniques and Students' Higher Order Thinking Skills, International Journal of Secondary Education, 4(1), 1-11, 2016.

[10] Nurkaeti, N. Polysa's Strategy: An Analysis Mathematical Problem Solving Difficulty In 5th Grade Elementary School, Eduhumaniora, 10(2), 140-147, 2018.

[11] Herawaty, D., Widada, W., Novita, T., \& Lubis, A, N, M, T. Students' Metacognition on Mathematical Problem Solving Through Ethnomathematics in Rejang Lebong, Indonesia, Journal of Physics: Conf. Series 1088 012089, 2018.

[12] Dwiyogo, W. D. Teaching and Learning Process: Thinking and Problem Solving, The Online Journal of New Horizons in Education, 6(3), 121-129, 2016.

[13] Siswono, T. Y. E., Kohar, A. W., \& Hartono , S. Secondary Teachers' Mathematics Related Beliefs and Knowledge about Mathematical Problem Solving, Journal of Physics: Conf. Series 812 012046, 2017.

[14] Permata, L. D., Kusmayadi, T. A., \& Fitriana, L. Mathematical Problem Solving Skills Analysis about Word Problems of Linear Program using IDEAL Problem Solver, Journal of Physics: Conf. Series 1108 012025, 2018.

[15] Hadge, B., \& Meera, B. N. How do They Solver it? An Insight into the Learner's Approach to the Mechanism of Physics Problem Solving, Physics Education Research, 8(1), 1-9, 2012.

[16] Chong, M., Shahrill, M., Putri, R. I. I., \& Zulkardi, Z. Teaching Problem Solving using Non-Routine Tasks, International Conference on Electrical, Electronics, Materials, and Applied Science, AIP Conference Proceedings 1952, 020020, 2018.

[17] Celebioglu, B., Yazgan, Y., \& Ezentas, R. Usage of Non-Routine Problem Solving Strategies at First Grade Level, Procedia Social and Behavioral Sciences, 2(20), 2968-2974, 2010.

[18] Polya. How to Solve it: A New Aspect of Mathematical Method. Priceton: Priceton University Press, 1973.

[19] Pratama, A. R., Saputro, D. R. S., \& Riyadi. Problem Solving of Student with Visual Impairment Related to Mathematical Literacy Problem, Journal of Physics: Conf. Series 1008 012068, 2018.

[20] Maryani, S., Pramudya, I., \& Slamet, I. The Effects of Emotional Intelligence on Students' Mathematical Problem Solving Ability, International Journal of Multicultural and Multireligious Undestanding, 6(5), 912-918, 2019.

[21] Johnson-Wilder, S., Lee , C., Brindley, J., \& Garton, E. Developing Mathematical Resilience in School Students Who Have Experienced Repeated Failure, International Conference of Education, Research and Innovation, 2015.

[22] Ariyanto, L., Herman, T., Sumarmo, U., \& Suryadi, D. Developing Mathematical Resilience of Prospective Math Teachers, Journal of Physics: Conf. Series 895 012062, 
2017.

[23] Reivich, K. \& Shatte, A. The Resiliency Factor: 7 Keys to Finding Your Inner Strength and Overcoming Life's Hurdles, New York: Three Rivers Press, 2002.

[24] Norman, E. Resiliency Enchancement: Putting The Strength Perspective Into Social Work Practice. New York: Columbia University Press, 2000.

[25] Maddi, S. \& Khoshaba, D. Resilience at Work: How to Succed No Matter What Life Throws at You. USA: American Management Association, 2005.

[26] Johnston-Wilder, S. \& Lee, C. Developing Mathematical Resilience, Bare Conference Paper University of Warwick, 2010.

[27] Yeager, D. \& Dweck, C. Mindsets That Promote Resilience: When Students Believe That Personal Characteristics Can be Developed, Educational Psychologist, 47, 302-314, 2012.

[28] Gurefe, N. \& Akcakin, V. The Turkish Adaptation of the Mathematical Resilience Scale: Validity and Reliability Study, Journal of Education and Training Studies, 6(4), 38-47, 2018.

[29] Kooken, J., Welsh, M. E., McCoach, D. B., Johnston-Wilder, S., \& Lee, C. Development and Validation of the Mathematical Resilience Scale, 1-26, 2015.

[30] Kooken, J., Welsh, M. E., McCoach, D. B., Johnston-Wilder, S., \& Lee, C. Measuring Mathematical Resilience: An Application of The Construct of Resilience to The Study of Mathematics, American Educational Research Association, 2013.

[31] Furner, J. M. \& Gonzalez-DeHass, A. How do Students' Mastery and Performance Goals Relate to Math Anxiety? Eurasia Journal of Mathematics, Science \& Technology Education, 7(4), 227-242, 2011.

[32] Lee, C. \& Wilder, S. Does Articulation Matter When Learning Mathematics?, Proceedings of British Society for Research Into Learning Mathematics, 28(3), 54-59, 2008.

[33] Goodall, J. \& Wilder, S. J. Overcoming Mathematical Helpness and Developin Mathematical Resilience in Parents: An Illustative Case Study, Journal Creative Education, 6(5), 2015.

[34] Gutman, L. M., Sameroff, A. J., \& Cole, R. Academic Growth Curve Trajectories From 1st Grade to 12th Grade: Effects of Multiple Social Risk Factors and Preschool Child Factors, Development Psychology, 39(4), 777-790, 2003.

[35] Fantuzzo, J., LeBoeuf, W., Rouse, H., \& Chen, C. C. Academic Achievement of African American Boys: A City-Wide, Community-Based Investigation of Risk and Resilience, Journal of School Psychology, 50(5), 559-579, 2012.

[36] Hafiz, M., Darhim, \& Dahlan, J. A. Comparison of Mathematical Resilience among Students with Problem Based Learning and Guided Discovery Learning Model, Journal of Physics: Conf. Series 895 012098, 2017.

[37] Pujiadi, Kartono, \& Asikin, M. Influence of Creative Problem Solving Aided with Interactive Compact Disk Towards Mathematics Learning Achievment of Grade X Students, International Journal of Education and Research,
3(3), 611-618, 2015.

[38] Himelo-Silver, I. Problem-Based Learning: What and How Do Students Learn?, Educational Psychology Review, 16(3), 234-266, 2004.

[39] Newman, T. What works in building resilience. London: Bernando’s, 2004. 